\title{
The Sense of Flow of L1 Audience for L2 Composition -A Pedagogical Implication from Cross-Pacific Exchange to the Teaching of English Writing
}

\author{
DU Yin-yin \\ Guangdong University of Foreign Studies, Guangzhou, China
}

\begin{abstract}
The present study focuses on the native readers' sense of flow, a construct frequently ignored in L2 writing studies. Based on the author's analysis of the communicative data in the web-based transnational peer editing activities named Cross-Pacific Exchange, an amendment is proposed for the currently well-accepted "input-output” models; that is, fluent output by classroom L2 learners may not always be accepted by native audience. Accordingly, L2 writing teachers should encourage their students to pay attention to their L1 readers' sense of flow, so as to enhance their own reader awareness, and improve the quality of their L2 composition through interaction with their L1 audience.
\end{abstract}

Keywords: sense of flow, reader audience, English writing, Cross-Pacific Exchange

\section{Introduction}

Cross-Pacific Exchange is an activity which was made possible through a joint program called "writing across borders" between a Midwestern U.S. university and a Southern Chinese university. Nine years in operation with 27 rounds, the program is committed to promoting on-line communication through writing between students from both universities. For every round of exchange, students communicate on a platform designed exclusively for the program. Both parties post their writings on the website, and then offer feedback in a comment box underneath the essay. This platform provides a space where students with different linguistic and cultural backgrounds can meet and communicate through writing. From the database of the 27 rounds exchanges and interactions, the present study mainly reports on the outcome of findings from the first nine rounds about how to encourage L2 learners to pay attention to their L1 readers' sense of flow, so as to enhance their own reader awareness and improve the quality of their L2 composition through interaction with their L1 audience.

\section{Focalization of "Flow"}

\section{A High Frequency Word from American Students' Comments}

Cross-Pacific Exchange enables Chinese students' English composition to have native readers. There are

Acknowledgements: This paper is funded by the program: A Corpus Research on a Tele-Collaborated Intercultural Peer Review Project (101-XGS17057).

DU Yin-yin, Master of Arts, Lecturer of English, Faculty of English Language and Culture, Guangdong University of Foreign Studies, Guangzhou, China. 
99 American student participants posting their comments on 178 Chinese students' compositions in the first nine rounds of exchange. It is found that the American peers choose to use the word of "flow" in 114 occasions altogether, such as:

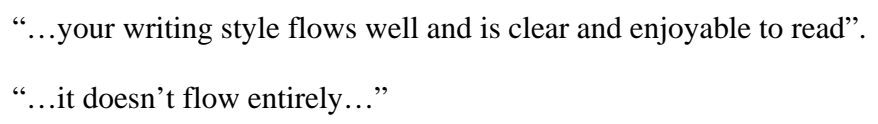

According to the third edition of Longman Dictionary of Contemporary English, "flow" can be used as a noun and a verb. When it is used as a noun, it means, "the continuous stream of words or ideas when someone is speaking, writing, or thinking about something"; when it is used as a verb, it means, "if conversation or ideas flow, people talk or have ideas steadily and continuously, without anything stopping or interrupting them". "Flow" is also a psychological term, first introduced by Hungarian psychologist Mihaly Csikszentmihalyi in 1970s. It refers to an optimal state of being and is characterized, among other things, by being intensely focused on a task and experiencing a feeling of timelessness. This concept has been applied to education and is familiarized by teachers with formal teacher education background. Thus, when American students comment on Chinese students' English writings, the frequently using of the word "flow" is probably affected by their writing teachers, which means "ideas continue smoothly" and "the words read continuously".

\section{Categorized Discussion on Implications of "Flow"}

Based on the meanings of "Flow", the following part will focus on American students' comments of "flow" during the nine rounds of exchange. The two charts categorize their comments into positive and negative opinions, which aim to find out (1) what compositions they regard as strong flow; (2) what elements of flow they notice in Chinese students' writing; (3) what revision advice they propose to those composition with weak flow.

\begin{tabular}{|c|c|c|c|}
\hline Categories & Number & Comments & Position \\
\hline \multirow{2}{*}{$\begin{array}{l}\text { Narrative } \\
\text { Flow }\end{array}$} & \multirow{2}{*}{11} & $\begin{array}{l}\text { You have a good overall narrative flow: that is, your sentences and } \\
\text { paragraphs combine nicely to express your larger idea. }\end{array}$ & Floor 1 , Article 14 , Round 1 \\
\hline & & $\begin{array}{l}\text { The plot points flowed smoothly together and I never really felt like the } \\
\text { story was jumping from place to place. }\end{array}$ & Floor 2, Article 6, Round 8 \\
\hline $\begin{array}{l}\text { Dialogue } \\
\text { Flow }\end{array}$ & 1 & The dialog flowed very well. & Floor 3 , Article 10, Round 5 \\
\hline \multirow{3}{*}{ Layout Flow } & \multirow{3}{*}{14} & $\begin{array}{l}\text { I think the essay was very well laid out and easy to follow; the flow was } \\
\text { great. It began with an example of the subject, an analysis of current } \\
\text { views, and ended with your own take on the discussion. }\end{array}$ & Floor 9, Article 10, Round 2 \\
\hline & & $\begin{array}{l}\text { I think that there is enough detail within the text to provide the reader } \\
\text { with a means to visualize what is going on and I think that everything } \\
\text { seems to flow, or be organized, in a coherent manner. }\end{array}$ & Floor 4, Article 11, Round 4 \\
\hline & & $\begin{array}{l}\text { I feel that this passage is very well organized in a way that the passage } \\
\text { flows smoothly without the reader pausing to understand any awkward } \\
\text { statements. }\end{array}$ & Floor 1 , Article 21, Round 7 \\
\hline Idea Flow & 6 & $\begin{array}{l}\text { I like the way Mr. Meizhong is introduced and I like the way the same } \\
\text { ideas flow throughout the paper. }\end{array}$ & Floor 2, Article 3, Round 3 \\
\hline \multirow{2}{*}{$\begin{array}{l}\text { Transition } \\
\text { Flow }\end{array}$} & \multirow[b]{2}{*}{13} & $\begin{array}{l}\text { The transitions you used made your essay flow smoothly instead of } \\
\text { making me feel like you were jumping around all over the place. }\end{array}$ & Floor 2, Article 3, Round 3 \\
\hline & & $\begin{array}{l}\text { The essay begins with a simple anecdotal story that nicely flows into the } \\
\text { purpose and central message of the essay. It flows very nicely and the } \\
\text { transitions were extremely appropriate and cohesive. }\end{array}$ & Floor 2, Article 9, Round 6 \\
\hline
\end{tabular}




\begin{tabular}{|c|c|c|c|}
\hline Categories & Number & Comments & Position \\
\hline \multirow{3}{*}{$\begin{array}{l}\text { Language } \\
\text { Flow }\end{array}$} & \multirow{3}{*}{10} & $\begin{array}{l}\text { The layout is consistent with a short story genre. The paragraphs are all } \\
\text { mostly the same length, and none stick out as too long or too short. The } \\
\text { shortness of the paragraphs contributes to a fast paced flow for the } \\
\text { audience. }\end{array}$ & Floor 1, Article 8, Round 6 \\
\hline & & $\begin{array}{l}\text { I followed it without having to think very hard, absorbed in the flow of } \\
\text { the material. }\end{array}$ & Floor 2, Article 16, Round 7 \\
\hline & & $\begin{array}{l}\text { The way you started each paragraph with "I am such a girl" not only } \\
\text { made the paper flow nicely, but it made your writing very powerful and } \\
\text { moving. }\end{array}$ & Floor 2, Article 4, Round 9 \\
\hline
\end{tabular}

Figure 1. Positive opinions (55 comments).

\begin{tabular}{|c|c|c|c|}
\hline Categories & Number & Comments & Position \\
\hline Diction Flow & 2 & $\begin{array}{l}\text { I would probably change a few words just to make the writing flow a bit } \\
\text { better. For example, I would change "I will never be able to input them } \\
\text { into my head" to "I will never be able to remember them". It goes along } \\
\text { with the casual tone of the paper. }\end{array}$ & Floor 6, Article 5, Round 3 \\
\hline \multirow[t]{2}{*}{ Passage Flow } & \multirow[t]{2}{*}{13} & $\begin{array}{l}\text { Overall, your passage flows easily with the contents of the sentences and } \\
\text { waves of information, however, some grammatical errors take away from } \\
\text { the otherwise remarkable passage, perhaps causing the reader to stumble } \\
\text { along the reading. }\end{array}$ & Floor 1, Article 3, Round 7 \\
\hline & & $\begin{array}{l}\text { Later in the paper, the line "Zhang stepped down the altar...” could flow } \\
\text { more smoothly if reworded to something like this, "Zhang stepped down } \\
\text { FROM the altar, his big mouth having shattered his image". }\end{array}$ & Floor 1, Article 13, Round 7 \\
\hline \multirow{3}{*}{$\begin{array}{l}\text { Language } \\
\text { Flow }\end{array}$} & \multirow{3}{*}{23} & $\begin{array}{l}\text { Also, sometimes you were too wordy. For example, “The day before the } \\
\text { peppermints mature, the king spent hours in observing a lively image of } \\
\text { them and tasting their fresh fragrances”. You could cut out a lot from this } \\
\text { sentence to make it flow better. You could rephrase it as, "The day before } \\
\text { the peppermints matured, the king spent hours imagining their fresh } \\
\text { fragrance". }\end{array}$ & Floor 4, Article 11, Round 4 \\
\hline & & $\begin{array}{l}\text { I understand the author is trying to make the story from both Emma and } \\
\text { Sam's point of view but it doesn't flow entirely and could be worded } \\
\text { better. }\end{array}$ & Floor 1, Article 15, Round 4 \\
\hline & & $\begin{array}{l}\text { Once last correction I can point out-in the 3rd to last } \\
\text { paragraph-instead of saying "and tell me his new discovery excitedly", } \\
\text { put the adverb immediately before the verb, so it would look like "and } \\
\text { excitedly tell me his new discovery". I think that would let the sentence } \\
\text { flow a little more smoothly. }\end{array}$ & Floor 2, Article 13, Round 6 \\
\hline $\begin{array}{l}\text { Paragraph } \\
\text { Flow }\end{array}$ & 1 & $\begin{array}{l}\text { You also could break up your paragraphs a bit by letting large blocks of } \\
\text { new quotations start new paragraphs. Other than that, though, I thought } \\
\text { your paper had a logical flow to it. }\end{array}$ & Floor 2, Article 7, Round 5 \\
\hline $\begin{array}{l}\text { Transition } \\
\text { Flow }\end{array}$ & 8 & $\begin{array}{l}\text { The paragraphs did not seem to flow well together. I suggest using some } \\
\text { words like "Furthermore" or "Additionally". }\end{array}$ & Floor 2, Article 12, Round 3 \\
\hline Structure Flow & 6 & $\begin{array}{l}\text { The distrust between teachers and students is a big issue, which can lead } \\
\text { to people choosing to take more online classes, etc. It would flow better } \\
\text { to then insert your paragraph about people becoming lazy as a result of } \\
\text { having internet-provided information at their fingertips. }\end{array}$ & Floor 2, Article 13, Round 8 \\
\hline Format Flow & 1 & $\begin{array}{l}\text { Visually, there are many spaces between your paragraphs. This may just } \\
\text { be a result of this computer program, but it disrupts the flow of the paper } \\
\text { when there are so many spaces in between paragraphs. }\end{array}$ & Floor 5, Article 9, Round 3 \\
\hline
\end{tabular}

Figure 2. Negative opinions (54 comments).

From the data of the above two charts, it is obvious that the numbers of positive and negative opinions are almost the same, which indicates that American students prefer to use the word "flow" to express their instinctual impression on Chinese students' writings. When they use the word "flow" to comment positively, they focus on their general impression and their comments are mainly from the perspective of text, such as the writing style and efficiency of arrangement, etc., which is the accumulation of knowledge from their writing 
course of schools. When they use the word "flow" to give negative comments, they focus more on the errors and mistakes at the level of diction and syntax, etc., which is due to their native readers' language sense. It is the combination of schools and society that equips the American students with an instinctual evaluation ability on the output of English.

It should be noted that during the first round of exchange, when the participants from American University who are mainly postgraduates majored in English comment on Chinese students' writings, they seldom use the word of "flow". From the collected data of this round, there is only one time that "flow" has been mentioned. It seems that the high frequent usage of the word "flow" among the American undergraduate might not be an academic term rather than a colloquial expression. They have not been trained systematically to Educational Psychology; therefore, they might have no idea about its academic connotation of this word. American undergraduate peers choose to use this word to express their instinctual impression only.

\section{Readers' Sense of Flow and Writers' Reader Awareness}

Acceptability Theory in text linguistics evaluates the text to see whether the text could be accepted and to help text producers to produce suitable texts by paying proper attention to the participants not only in text communication, but also emphasizing mental operation process (Liu, 2011). This theory inspires the present study to explore further on readers' sense of flow and encourage student-writers to enhance their reader awareness.

\section{Difference Between Flow and Fluency}

When "flow" is discussed in the context, there is another word- "fluency" coming up to compare to "flow". In EFL teaching, Fluency First Approach is first introduced by MacGowan-Gihooly. This approach is enabling students to become fluent in writing and reading before having to produce grammatically correct pieces or to comprehend academic material (MacGowan-Gihooly, 1991). In the practice of speaking and writing, fluency is prior to clarity and correctness. Wang's teaching model of Length Approach in English writing courses encourages Chinese students to write increasingly long compositions, which aims to increase learners’ English proficiency through writing tasks (Wang, 2005). Based on motivating tasks, the length of writing is manipulated and emphasized and use of English follows an urge to express ideas. Writing longer for each assignment gives learners a sense of achievement and thereupon motivates more L2 use and absorption of L2 input. This approach accords with Swain's Output Theory on improving English proficiency (Swain, 1985; 1995).

Wang further develops that "what co-occurs with a linguistic form being learned will affect its retrieval and use" (Wang, 2009). If a language learner learns English in a non-English spoken country, the target language discourse does not exist. Therefore, the environment lacks adequate positive evidence, which could not guarantee the learner to use English more correctly than more fluently. The classroom setting would not even solve the problem properly. Thus, the Cross-Pacific Exchange activity provides an authentic situation for students to interact with native readers whose mother tongue is English. It facilitates the students to be more aware of their usage of English in the writings. All in all, fluency is the subjective experience of the learners and flow is the objective effect on the readers. If student-writers are more sensed with readers' awareness, they would be more motivated to concern about native readers feedbacks. All in all, the small step from fluency to flow would lead to a big stride toward the correctness in students' writings. 


\section{Sense of Flow and Grammaring}

As a reader, what elements should be taken into consideration to get a sense of flow? The following feedback from American student may indicate the possible meaning of flow when it is used to refer to positive comments.

Floor 4, Article 1 (Round 6): Who is the Murderer?

...Your story flowed well and made sense. You are very good at incorporating dialogue, which I think is really important in short stories like this one. You also did a good job keeping the story simple and easy to follow by not having too many characters or too much happening in a short time. You stayed focused throughout the story and I was able to easily follow the plotline. You did a nice job setting the scene at the beginning, and did a pretty good job balancing description of time and place with dialogue. You also did a good job transitioning between ideas and action in the story and your transitions were not awkward or forced.

From the above comments, this American student summarizes the sense of "flow" as the cohesion, characterization, plotting, balance between setting of time and usage of rhetorical devices. This commentary is not merely from the instinctual impression of native speakers, but from students' accumulation of "skills" knowledge acquired from the writing courses. Next "skill" awareness will be discussed with referring to Larsen-Freeman's concept of "grammaring”.

Larsen-Freeman emphasizes on grammar as one of the skills as listening, speaking, reading, and writing. She introduced the concept of grammaring based on the definition of grammar as "one of the dynamic linguistic processes of pattern formation in language (2003, p. 142). She further explains that "students will best acquire the structures and patterns when they are put into situations that require them to use structures and patterns for some meaningful purpose other than decontextualized or mechanistic practice” (p. 117). Of the three dimensions of grammar, Larsen-Freeman believes that form is learned through repetition; meaning through associative learning and use through consideration of the communication context (pp. 42-43).

The sense of flow is more like the meaningfulness of Larsen-Freeman's concept of "grammaring", but meaningfulness is the writer's desire to achieve in his writing, while the sense of flow is the reader's impression on the writing. Even though the writer could achieve meaningfulness in his writing, reader's flow might not be continuous and smooth. It is exactly like what happened during the Cross-Pacific Exchange: no matter what kind of input and output tasks have been designed by the teacher in class, no matter how students actively participated the class discussion, their writings are not always responded with smooth flow. It is suggested to interact with native speakers, which would enable the students to be aware of the response and feedback on their second language output. If there are problems in the language expressions during the interaction, they would reflect and negotiate with native readers in order to achieve the meaningfulness, next, accuracy and appropriateness.

\section{Further Discussion on Meaningfulness}

Language is to express meaning and communication with language is a dynamic negotiation of meaning-making process. The grammaring competence could be measured through meaningfulness. If a sentence has no grammatical mistakes, it may not be a meaningful sentence, such as the example given by Chomsky (1957): “Colorless green ideas sleep furiously”. If teaching of English writing only emphasizes on the accuracy of language system, the flow of students' output will not be guaranteed to be followed by the native readers. Thus, students-writers' efforts in achieving meaningfulness in their writings is in proportion to the improvement of their reader awareness on flow. 
There are different possibilities which result in the weak flow in Chinese students' writing. First of all, inadequate interlanguage vocabulary may be one of the reasons for mal-meaningfulness. Chinese students acquire new vocabulary in other courses, such as white collar, pagan, etc., and they would like to use it in their writings. But American students are confused at the usage of these words for there are no unanimously agreed meaning of these words. Different people might have different understanding in different contexts. Chinese students respond on it: "I have never thought about it for almost all of my classmates get my point when I say these words". It cannot be denied that some English vocabulary might confuse native readers if they are uprooted in specific classroom discourse context. For these words, their meanings and implications may only be shared by a small group of people.

Secondly, meaningfulness in second language writing may also relate to the cultural differences. One of the American students notices an interesting problem in Chinese student's writing: "One thing I noticed was that you used bachelorhood to describe a woman, which isn't something you generally do in English. I'm not sure what the female equivalent of bachelorhood is, but a bachelor is solely male". This kind of readers puzzles could only be solved through negotiation.

Thirdly, problems with the rhetoric of Chinese students' writing may lead to poor meaningfulness. There is an American student commenting:

"20 years passed and the boy became a brilliant architect and had much work to do so he also kept himself working late"-It might be better to say something more along the lines of 20 years passed, and the boy became a brilliant architect. Due to the amount of work he had to do each day, he also began working late into the night. (Floor 1, Article 30, Round 10)

The American student's revised sentence clarifies the meaning and simplifies the logic in the original one, which seems to be a better choice in terms of rhetoric.

During the Cross-Pacific Exchange, Chinese student-writers not only interact with native readers but also read other peers' writings as well, which is an opportunity for them to observe the process of their peers' interaction and they would be aware of some aspects they might ignore. Sometimes, Chinese students could not sense the flow of their peers' writing, while American peers comment with positive feedback on its flow. For example, American students may confirm Chinese students' proper use of English idioms but Chinese peers are confused about these phrases and expressions: "I am very impressed with the grammar and language of this passage. It all makes sense and there are even some native phrases like 'brimming with confidence' or 'getting hitched"” (Floor 1, Article 20, Round 7). During the exchange, Chinese students are awakened to the usage of "native phrases" and they will try these expressions in their own writings, while the student-writers who are praised are quite encouraged to use more idioms.

\section{Conclusion}

The present study focuses on the native readers' sense of flow, a construct frequently ignored in L2 writing studies. Based on the author's analysis of the communicative data in the web-based transnational peer editing activities named Cross-Pacific Exchange, an amendment is proposed for the currently well-accepted "input-output" models; that is, fluent output by classroom L2 learners may not always be accepted by native audience. Accordingly, L2 writing teachers should encourage their students to pay attention to their L1 readers' sense of flow, so as to enhance their own reader awareness, and improve the quality of their L2 composition through interaction with their L1 audience. 


\section{References}

Chomsky, N. (1957). Syntactic structures. The Hague: Mouton.

Larsen-Freeman, D. (2003). Teaching language: From grammar to grammaring. Boston: Heinle \& Heinle.

Liu, C. (2011). Acceptability theory in text linguistics and reception theory in literary criticism. Foreign Literature, 5, $104-110$.

MacGowan-Gilhooly, A. (1991). Fluency before correctness: A whole-language experiment in college ESL. College ESL, 1, 37-47.

Swain, M. (1985). Communicative competence: Some roles of comprehensible input and comprehensible output in its development. In S. Gass and C. Madden (Eds.), Input in second language acquisition (pp. 235-253). Rowley, MA: Newbury House.

Swain, M. (1995). Three functions of output in second language learning. In G. Cook and B. Seidlhofer (Eds.), Principles and practice in applied linguistics: Studies in honour of H. G. Widdowson (pp. 125-144). Oxford: Oxford University Press.

Wang C. (2005). The length approach. ELT, 4, 15-26.

Wang C. (2009). A study of the interrelationship between L2 learning variables and L2 use. China Foreign Language, 5, 53-59. 